June 2003 - NREL/TP-550-34008

\title{
Analysis of NREL Cold-Drink Vending Machines for Energy Savings
}

M. Deru, P.Torcellini, K. Bottom, and R. Ault

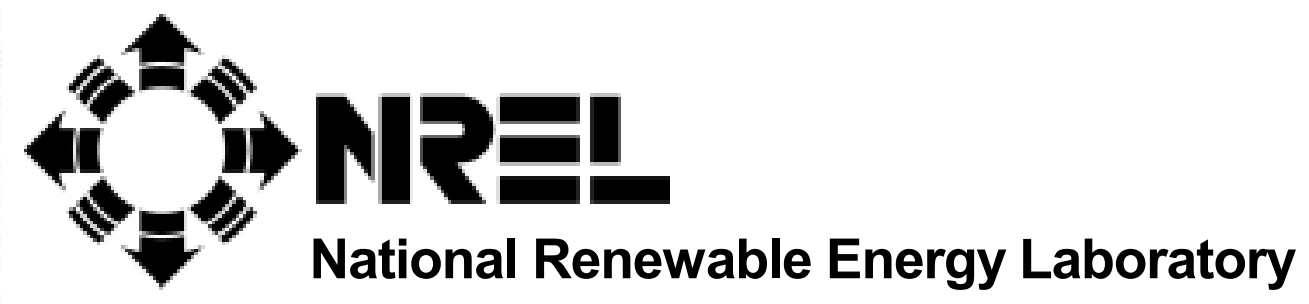

1617 Cole Boulevard

Golden, Colorado 80401-3393

NREL is a U.S. Department of Energy Laboratory

Operated by Midwest Research Institute $\bullet$ Battelle $\bullet$ Bechtel

Contract No. DE-AC36-99-G010337 


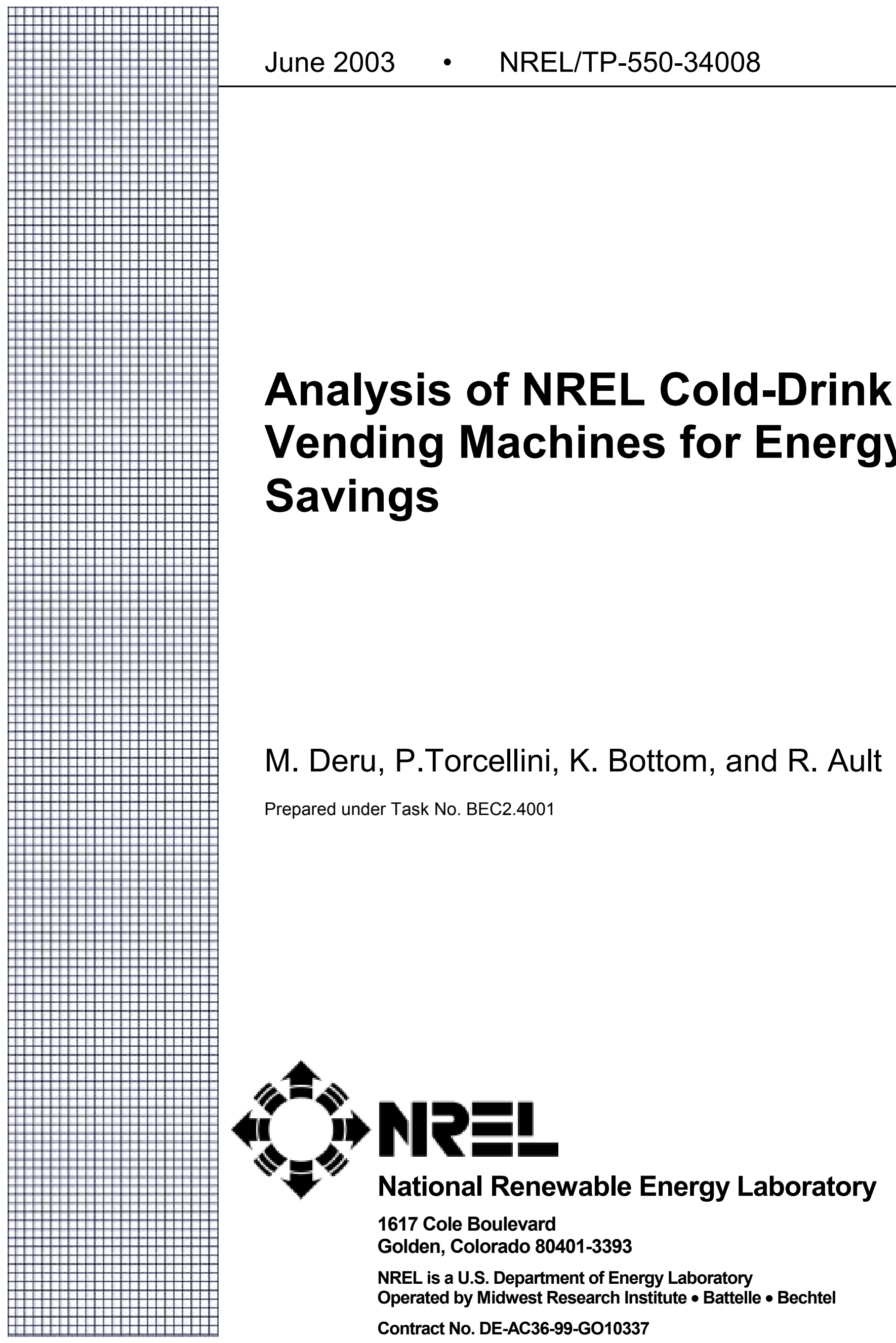




\section{NOTICE}

This report was prepared as an account of work sponsored by an agency of the United States government. Neither the United States government nor any agency thereof, nor any of their employees, makes any warranty, express or implied, or assumes any legal liability or responsibility for the accuracy, completeness, or usefulness of any information, apparatus, product, or process disclosed, or represents that its use would not infringe privately owned rights. Reference herein to any specific commercial product, process, or service by trade name, trademark, manufacturer, or otherwise does not necessarily constitute or imply its endorsement, recommendation, or favoring by the United States government or any agency thereof. The views and opinions of authors expressed herein do not necessarily state or reflect those of the United States government or any agency thereof.

Available electronically at http://www.osti.gov/bridge

Available for a processing fee to U.S. Department of Energy and its contractors, in paper, from:

U.S. Department of Energy

Office of Scientific and Technical Information

P.O. Box 62

Oak Ridge, TN 37831-0062

phone: 865.576 .8401

fax: 865.576.5728

email: reports@adonis.osti.gov

Available for sale to the public, in paper, from:

U.S. Department of Commerce

National Technical Information Service

5285 Port Royal Road

Springfield, VA 22161

phone: 800.553.6847

fax: 703.605.6900

email: orders@ntis.fedworld.gov

online ordering: http://www.ntis.gov/ordering.htm 


\section{TABLE OF CONTENTS}

INTRODUCTION

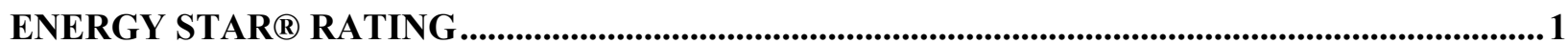

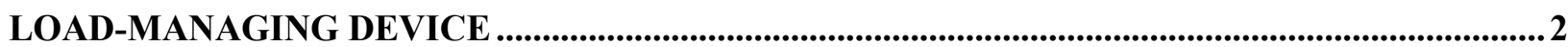

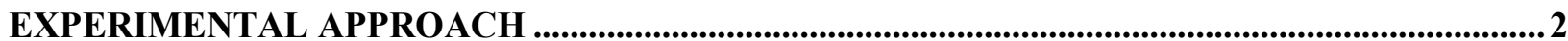

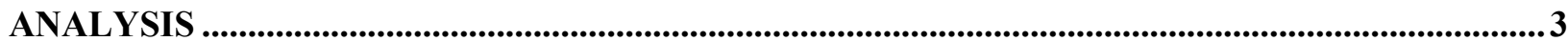

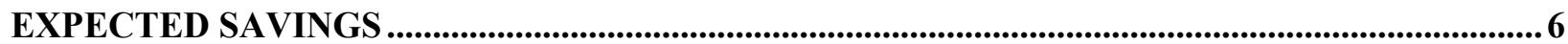

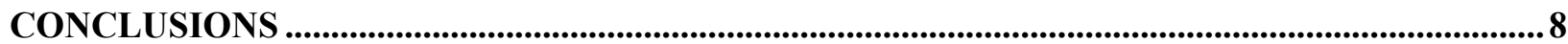

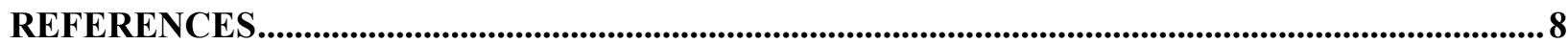

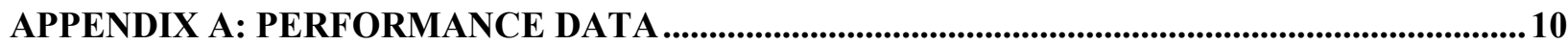

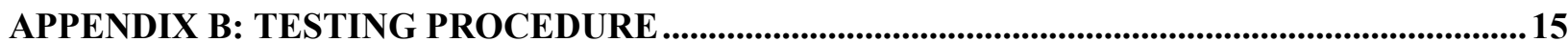




\section{Introduction}

Refrigerated vending machines consume a significant amount of energy to supply cold products. Measurements at the National Renewable Energy Laboratory (NREL) have shown that a typical machine that dispenses $50012-\mathrm{oz}$ cans with an illuminated front consumes between 7 and $11 \mathrm{kWh} /$ day in an office environment. Measurements by other groups show similar results; for example, a study for the Sacramento Municipal Utility District (SMUD) reported energy consumption of 8 to $13 \mathrm{kWh} /$ day [1]. For comparison, new Energy Star ${ }^{\circledR}$ certified residential refrigerators use 1-2 kWh/day [2]. One reason for the high-energy use is that the manufacturers and owners of the vending machines generally do not pay for the energy to run the machines; therefore, they have little incentive to improve the energy efficiency of the machines. The building owners, who pay the utility bills, have little choice in the type of vending machine that is deployed at their site.

As a building owner, NREL also has little control over the vending machines deployed at its site. However, NREL staff, as part of Sustainable NREL, an initiative to improve the overall energy and environmental performance of the lab, decided they could control how those machines were used. As part of this effort, the cold-drink vending machines across the lab were analyzed for potential energy saving opportunities. This report details the monitoring and the analysis of two energy conservation measures (ECMs) applied to the cold-drink vending machines. The first ECM was to utilize a load-managing device designed for vending machines and the second was to simply remove the advertising lights in the front of the machine. The load-managing device was also studied to determine if it had any adverse effects on the operation of the vending machines or on the temperature of the delivered product.

There are sixteen cold-drink vending machines on the NREL campus. Both ECMs were only applied to fifteen of these machines. One machine was only delamped because it is in an area that is continuously occupied and the load-managing device would produce very little savings. The details of the machines are listed in Appendix A. Measurements were only taken on ten of the machines and the savings for the others were estimated based on the measured data.

There may be a concern that delamping the advertising light fixtures might reduce the amount of product sold because people will think the machines are not in service. However, consumers in an office environment with no other beverage choices are a captive audience, and they quickly learn that the machines are always in service. In order to educate the occupants and ensure them that the machines were still in service, signs indicating that the lights were turned off to save energy were placed on the machines when they were first delamped. Additionally, the beverage vending company was consulted prior to delamping the machines.

\section{Energy Star® Rating}

An effort to create an Energy Star standard for rating vending machine energy performance [3], which is hoped to improve the average energy performance, is underway. The initial draft of this standard states that Energy Star qualifying models shall consume a quantity of energy in a 24-hr period equal to or less than the value obtained from the equation shown below:

$$
\mathrm{Y}=0.55(8.66+0.009 \times \mathrm{C})
$$

Where $\mathrm{Y}$ is the $24-\mathrm{hr}$ energy consumption ( $\mathrm{kWh} /$ day) and $\mathrm{C}$ is the machine product capacity expressed as the maximum number of equivalent $12 \mathrm{oz}(355 \mathrm{ml})$ cans the machine can hold. This would require that a 500-can capacity machine consume no more than $7.2 \mathrm{kWh} /$ day. A 600-can and an 800-can capacity machine may consume no more than $7.7 \mathrm{kWh} /$ day and $8.7 \mathrm{kWh}$ /day respectively. This draft of the standard is not very stringent and will likely be revised. 


\section{Load-Managing Device}

The load-managing device tested in this study uses a passive infrared occupancy sensor to turn off the vending machine when the surrounding area is unoccupied and turn it back on when the area is reoccupied. The load manager also monitors the ambient temperature while the vending machine is off, and it powers up the machine when required to ensure that the product stays cold. In addition, the load manager monitors electrical current used by the vending machine so that it is not shut off while the compressor is running to prevent a high head pressure start from occurring. This process reduces maintenance costs and extends the life of the vending machine by significantly reducing the number of compressor cycles.

There have been numerous studies on the performance of this particular load-managing device for vending machines [4]. Most of the studies focus on simple energy savings estimations, which vary between $24 \%$ and $76 \%$. One detailed study focused on the electrical demand savings potential of the device [1]. This study estimated a peak demand reduction of $22 \mathrm{~W}$ per installation in an office environment. This small reduction can be explained by the fact that the vending machines are often located in occupied areas during the peak demand periods, and therefore, there is little savings produced by the load manager. This study also estimated an average annual energy savings of $37 \%$ for applications across different building types. Finally, an independent evaluation of the load manager was completed for the manufacturer [5]. The product was found to have very good to excellent integrity, manufacturing, and serviceability. In an unoccupied $90^{\circ} \mathrm{F}$ test chamber, the load manager was found to reduce energy consumption by $48 \%$ and did not adversely affect the product temperature. In addition, the report concluded that the reduced cycling of the compressor and condenser fan would increase the life of the vending machine.

\section{Experimental Approach}

Two existing protocols for rating vending machine performance are ASHRAE Standard 32.1-1997 [6] and CAN/CSA-C804-96 [7]. These two methods are very similar and are designed to test the machines in tightly controlled conditions for performance rating. They are not meant for testing machines under actual operating conditions. A new method of testing the performance of the machines was devised for two levels of information. The details of the testing procedures are found in Appendix B.

The purpose of the first test was to determine the total energy consumption of the vending machines with and without applying the ECMs. This was done by measuring the energy consumption over the period of one week for each condition using a portable plug-in, watt-hour meter. Three different operating conditions were measured: without the load manager, which established a base case; with the load manager; and with the load manager and the internal advertising lights removed. The internal advertising lights consist of two T-12 50-W fluorescent bulbs. The average ambient temperature during the test periods was also recorded. In four of the vending machines, the advertising lighting had already been removed so all the measurements were conducted with the lights off. The average power consumed with the lights on was estimated based on measurements from similar machines. Machines 11 to 16 were not monitored and the results were estimated based on the measurements of similar models.

The second testing procedure was performed to gain a better understanding of how the load-managing device saves energy and affects product temperatures. This test consisted of instantaneous current readings at one-minute intervals and room air temperature and machine internal temperature measurements at 15-minute increments. This test was performed on the number one and two vending machines listed in the tables in Appendix A, which were already delamped from the first test. It is expected that the other machines will respond in a similar fashion. 


\section{Analysis}

The results of the energy data taken for the three different cases are found in Figure 1 and Appendix A. Figure 1 compares the average power consumed by each machine over a one-week period under the three test conditions: baseline, load manager, and load manager plus delamping. The values for machines 1115 are all estimated and are represented by machine 11 in Figure 1. On average, each vending machine consumes approximately $8.3 \mathrm{kWh} /$ day when operating under baseline conditions, $5.6 \mathrm{kWh} /$ day when operating with the load manager alone, and $3.7 \mathrm{kWh} /$ day when operating with the load manager while delamped. The measured minimum, maximum, and average energy savings for the two test cases and the estimated savings for delamping alone are shown in Table 1. This first testing procedure shows that the load manager alone produced an average energy savings of 33\%, and disconnecting the advertising lamps with the load manager can save approximately $56 \%$ of the energy. Assuming that the power of the advertising lamps is $100 \mathrm{~W}$, the average energy savings from just delamping the machines is approximately $29 \%$.

The energy savings achieved by the load manager in other applications will depend on the vending machine, the ambient conditions, and the occupancy patterns. The occupancy schedule for the office environment in these tests is typically 10-12 hours, five days a week plus occasional occupancy at night and on weekends by cleaning and security personnel.

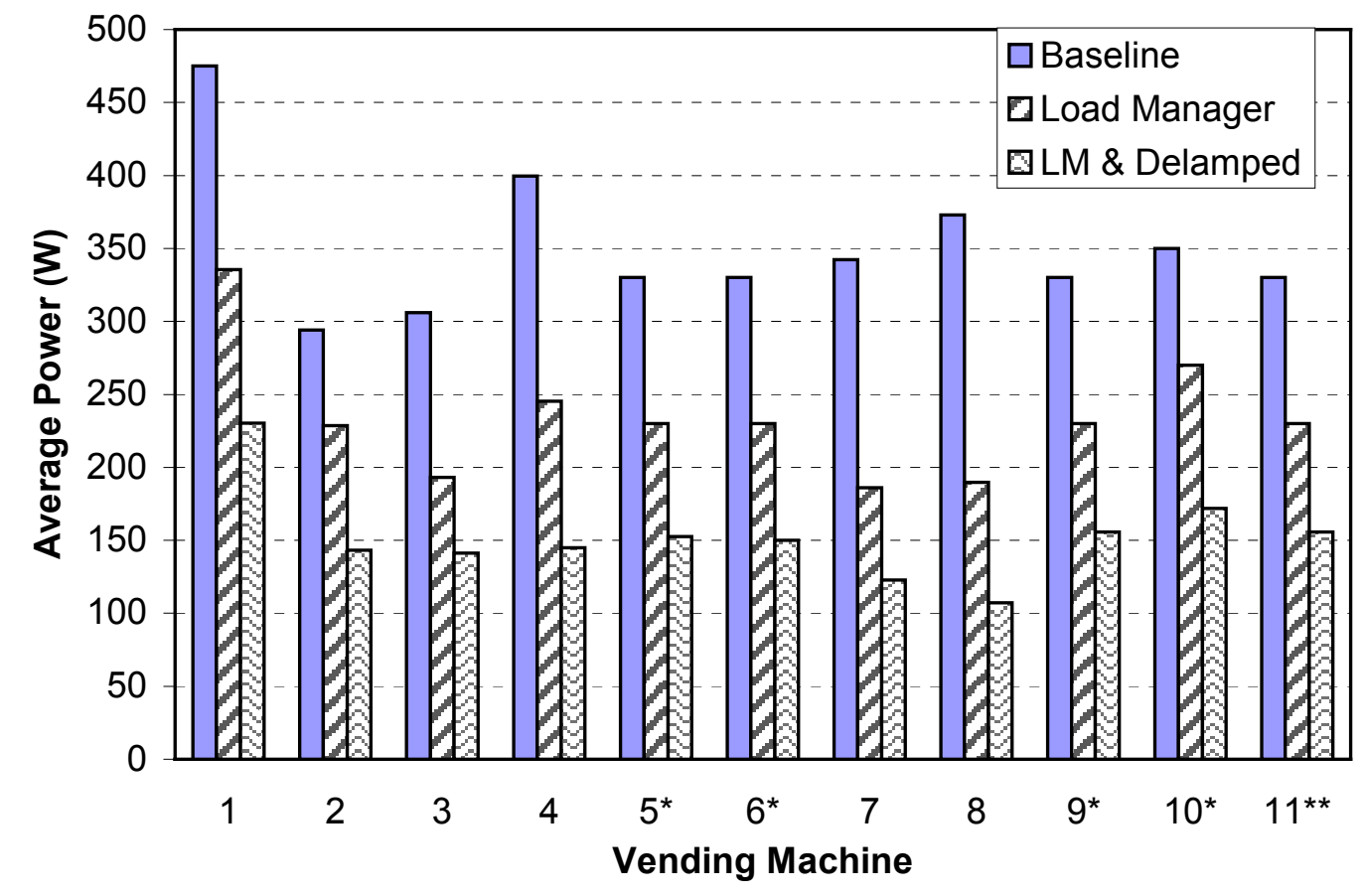

Figure 1: Average power consumption of NREL vending machines for three test cases. * Lights on values estimated ${ }^{* *}$ All values estimated 
Table 1: Percent energy savings for energy conservation measures

\begin{tabular}{|l|c|c|c|}
\hline \multicolumn{1}{|c|}{ Energy Conservation Measure } & Min & Max & Avg \\
\hline Load manager & $22 \%$ & $50 \%$ & $33 \%$ \\
\hline Load manager \& delamping & $51 \%$ & $71 \%$ & $56 \%$ \\
\hline Delamping (estimated) & $27 \%$ & $34 \%$ & $29 \%$ \\
\hline
\end{tabular}

The second level of testing was performed on two machines (\#1 and \#2 from Figure 1) with and without the load manager and no advertising lights for either test case. These machines are located side-by-side in a break room that has frequent occupation throughout the day. The test revealed some interesting information about how the load manager affects vending machine operation and product temperatures. A look at the current profiles in Figures 2 and 3 for one day during each testing period shows how the load manager affects the operation. The test conditions were not identical for each period as the quantity of the product changed slightly and the room air temperatures were slightly different. The average room temperatures for the two tests were $74.5^{\circ} \mathrm{F}$ for $10 / 23 / 02$ and $73.0^{\circ} \mathrm{F}$ for $10 / 30 / 02$. The temperature variation represents about $4 \%$ of the temperature difference from the room air to the product.

The top graph of Figure 2 shows that vending machine \#1 never shuts off completely without the load manager. It draws a $1 \mathrm{~A}$ current between compressor cycles, probably for condenser fan operation. The load manager turns the machine off during unoccupied periods as shown in the bottom graph in Figure 2. This represents about an $8 \%$ energy savings. The load manager also reduces the frequency of the compressor cycles during unoccupied periods, which produces a $21 \%$ energy savings.
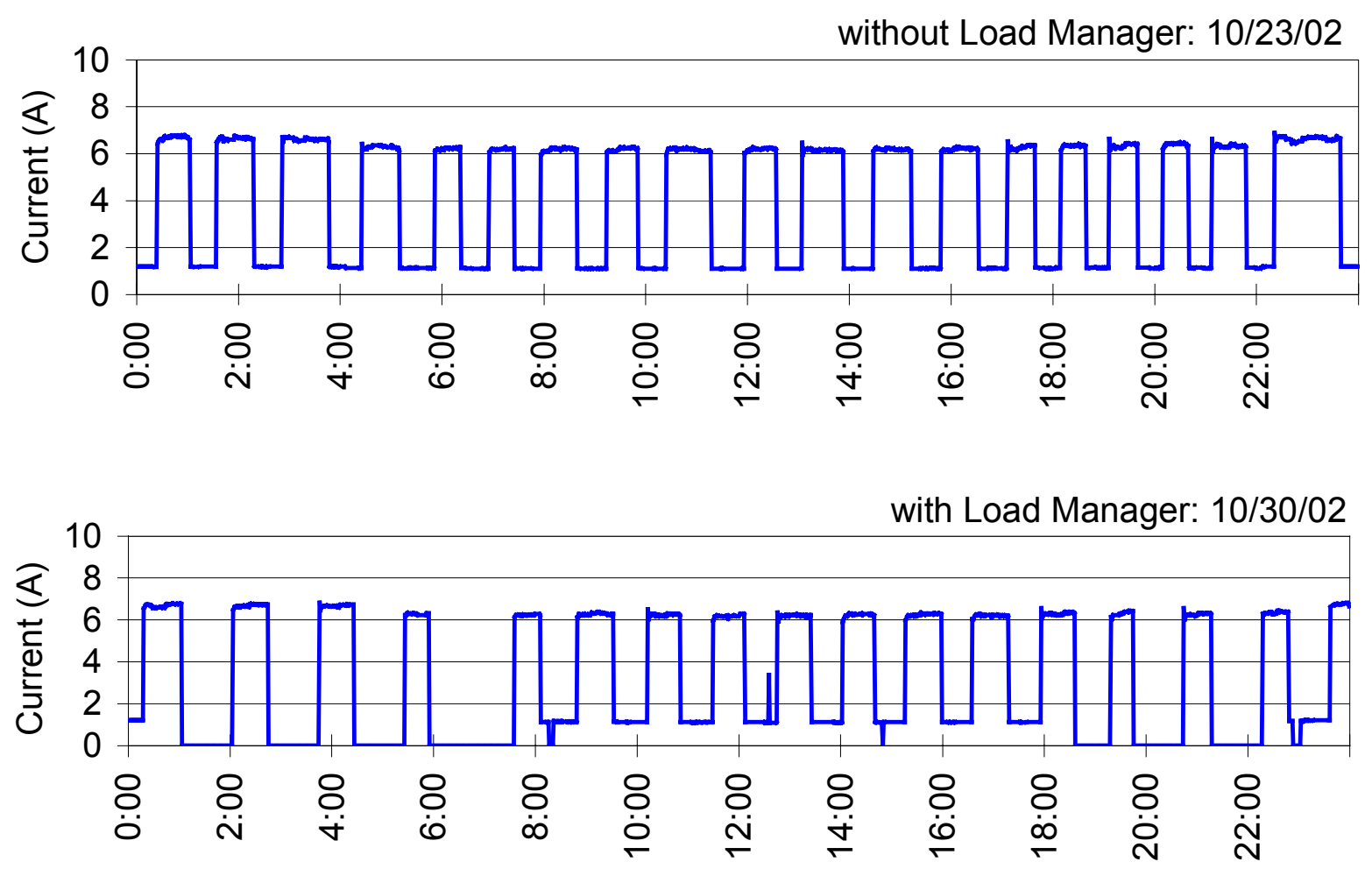

Time

Figure 2: Current profile for vending machine \#1 with and without the load manager 
Figure 3 shows the current profile for vending machine \#2 with and without the use of the load-managing device. This machine uses less energy than \#1 (as shown in Figure 1) and has more frequent and shorter compressor cycles. There is also no current draw between compressor cycles. The use of the load manager produces fewer and longer compressor on cycles at night. The savings for the one-day shown in Figure 3 is approximately $8 \%$. The savings measured by the plug in watt-hour meter during a different test period was approximately $14 \%$.

without Load Manager: 10/23/02
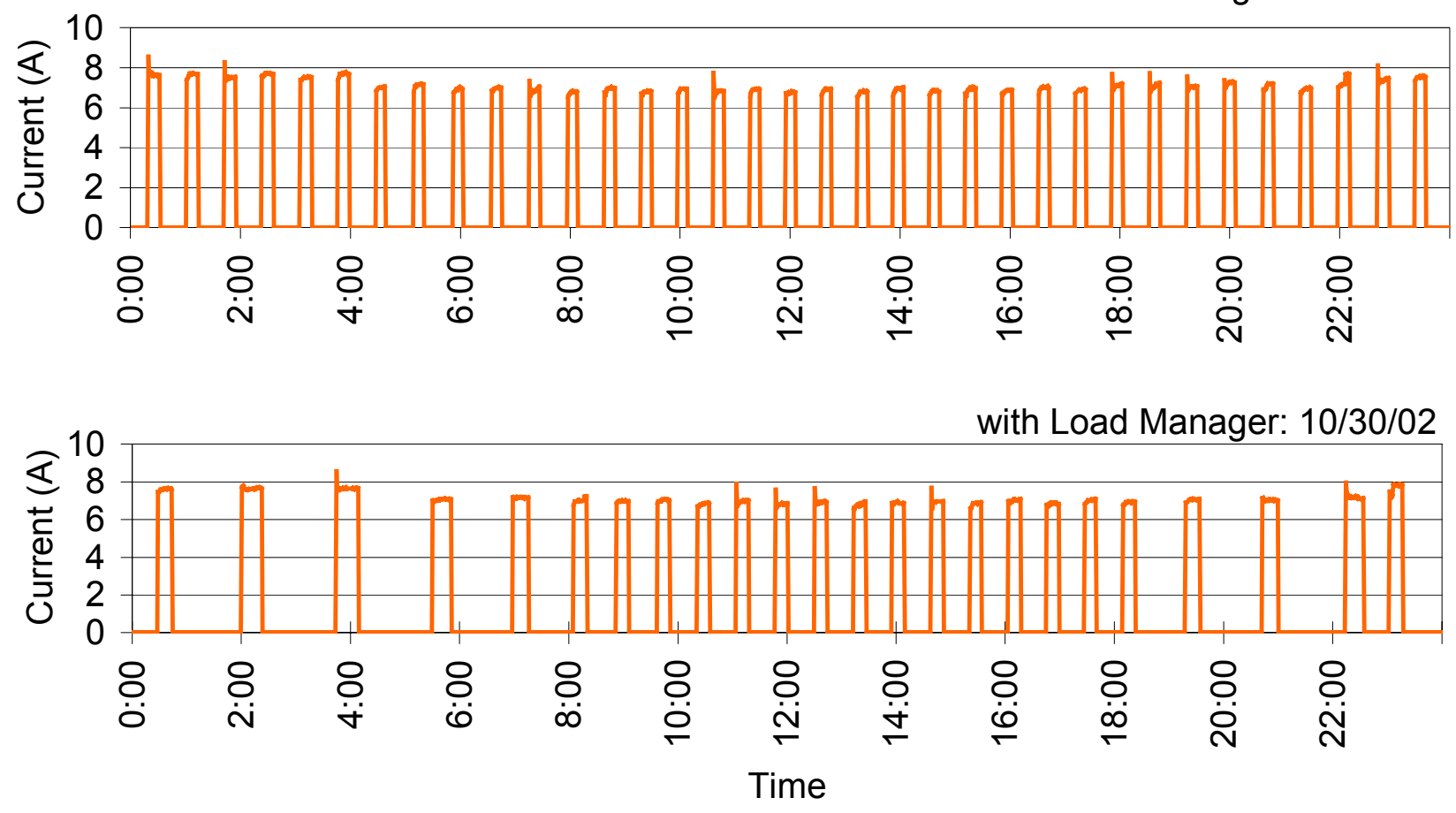

Figure 3: Current profile for vending machine \#2 with and without the load manager

A temperature sensor was placed inside the vending machines in the center next to the product to obtain temperature readings from within the machine. Table 2 shows the maximum, minimum, and average internal temperature for vending machine \#1 during the weeklong testing periods.

Table 2: Vending Machine \#1 Internal Temperature Data ( $\left.{ }^{\circ} \mathrm{F}\right)$

\begin{tabular}{|l|c|c|c|c|}
\hline \multicolumn{1}{|c|}{ Case } & Average & Maximum & Minimum & Avg. Room \\
\hline \hline With load manager & 35.5 & 43.0 & 32.8 & 76.0 \\
Without load manager & 36.6 & 40.2 & 32.8 & 77.6 \\
\hline
\end{tabular}

The use of the load manager has a negligible effect on the product temperature. In fact, the average internal temperature with the load manager was slightly lower than without the load manager; however, the average room temperature was also slightly cooler during the period with the load manager. For a 
closer look at the load manager's effect on product temperature, an interior temperature profile for vending machine \#1 over one full weekday was recorded as seen in Figure 4. The temperature profiles were taken during a different testing period than the current profiles shown in Figure 2. The decrease in the frequency of temperature fluctuations with the use of the load manager was caused by fewer and longer compressor cycles with the load manager.

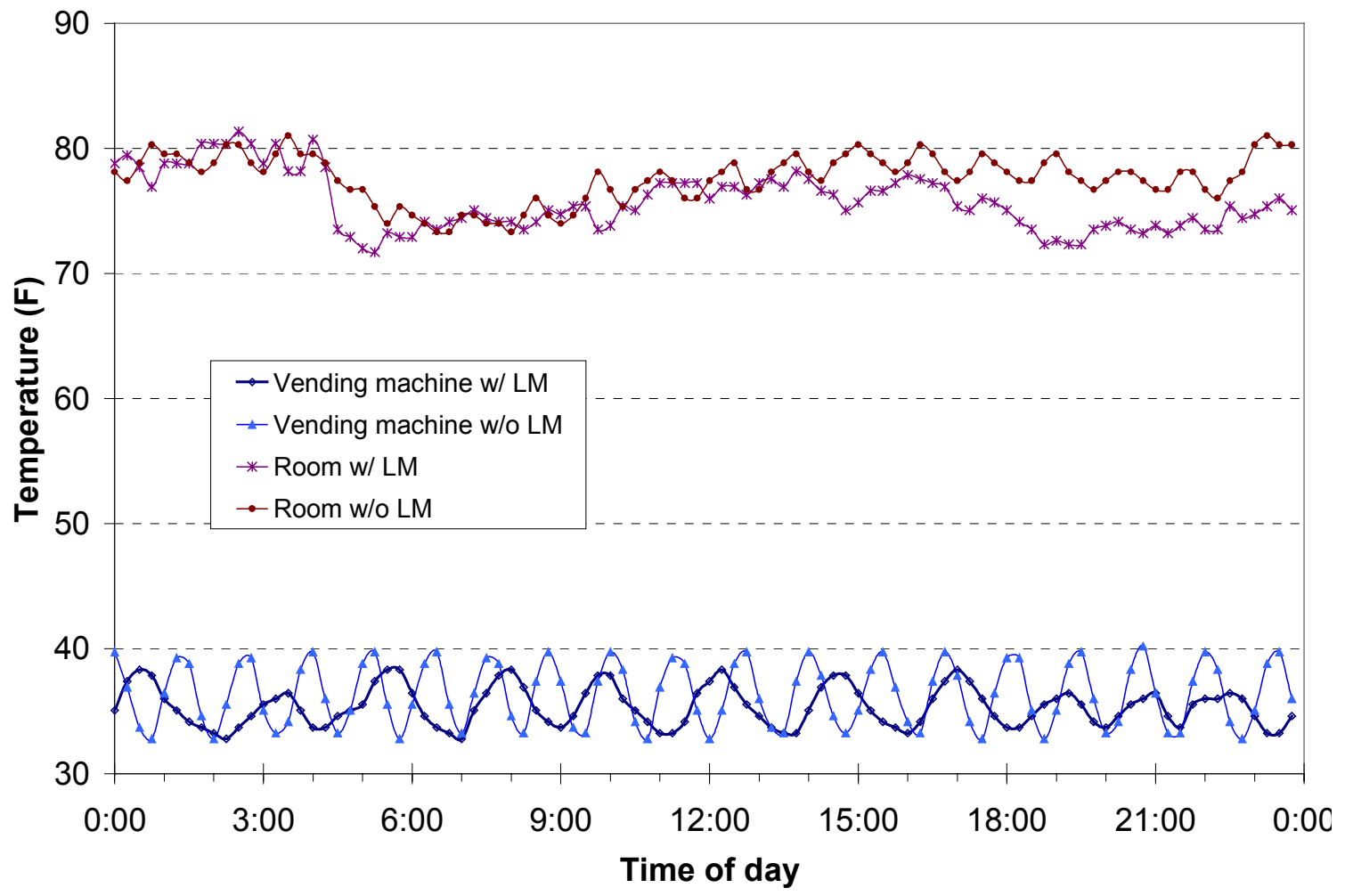

Figure 4: Room and vending machine \#1 internal temperature profiles for the tests with and without the load manager

\section{Expected Savings}

For the vending machines tested in this study, the load manager reduced the energy consumption by an average of 33\%. Disconnecting the advertising lamps along with the load manager reduced the energy consumption by 55\%. The estimated annual energy savings of the three ECMs applied to the 15 machines at NREL are 14.8 MWh for the load manager, 13.2 MWh for delamping, and 25.2 MWh for the load manager and delamping. The actual energy savings is the latter number because all the machines have a load manager and are delamped.

The energy cost savings is more difficult to determine because it is related to the reduction in the energy used and the reduction in the electrical demand. All of the vending machine studies, except one reviewed by the authors that included cost savings analysis, used a fixed energy cost rate for the cost savings estimates. Most commercial buildings have a utility rate structure based on a demand charge and a low energy cost rate. The reduction in the peak demand is very difficult to determine because it depends on the coincidence of the electrical loads. The areas of the vending machines are normally occupied during business hours; therefore, very little, if any, demand reduction will be attributed to the load managers. The SMUD study reported only a $22 \mathrm{~W}$ demand savings per machine with the load manager during normal business hours for offices; however, there were significant demand savings during nonoccupied hours [1]. One of the 17 machines in this study was delamped, which represents about one fourth of the $22 \mathrm{~W}$ demand savings. 
NREL has buildings at two different sites with different electrical rate structures. For 2002, the South Table Mountain (STM) site has an energy charge of $\$ 0.01612 / \mathrm{kWh}$ and demand charges of $\$ 7.71 / \mathrm{kW}$ for 8 a.m. -10 p.m. and $\$ 5.36 / \mathrm{kW}$ for 10 p.m. to 8 a.m. The National Wind Technology Center (NWTC) has an energy charge of $\$ 0.01612 / \mathrm{kWh}$ and a demand charge of $\$ 12.8 / \mathrm{kW}$.

The following assumptions were made to estimate the energy cost savings:

1. Vending machines with no ECMs applied contribute $2 / 3$ of the average power consumption per machine to the building peak demand. This is estimated from the SMUD study for vending machines in offices.

2. Load managers on vending machines in areas that are normally occupied during business hours do not contribute to building peak demand reduction during this time period (i.e., the demand charge is calculated as in assumption \#1). This applies to all vending machines.

3. Load managers reduce the building peak demand calculated under assumption \#1 in half during unoccupied times (i.e., the peak demand is $1 / 3$ of the average power consumption). This reduction is only relevant to the machines at the STM site, which has a nighttime demand charge.

4. Delamping a vending machine provides a constant $100 \mathrm{~W}$ reduction in power consumption compared to the baseline case.

5. The average power consumption of the vending machines was taken as that measured over a oneweek period with the plug-in watt-hour meter.

The annual energy cost savings by kWh, demand, and total for each of the ECMs is shown in Table 3 for all the vending machines. The use of the load manager and delamping saves approximately $\$ 635$ per year. Delamping the machines saves more money than using the load manager alone because of the savings in the demand charges. These savings are due to the assumption that the load manager will not reduce the daytime demand charges. The demand cost savings for the load manager are only due to the reduction of the nighttime demand charge for the STM site. A simple payback analysis of the load managers is shown in Figure 5. This graph uses only the initial purchase cost of the load managers and not the installation costs. In addition, no inflation of the energy cost or discount rate was taken into account. This analysis estimates that it will take approximately six years for the load managers to pay for themselves if they are used with no delamping. This payback period is longer than reported in other studies of this load manager due to the relatively low electrical energy costs.

Another method of calculating the energy cost savings is to use the virtual rate, which is equal to the total electric charge divided by the total $\mathrm{kWh}$ 's used. The virtual rate for the STM site is $\$ 0.045 / \mathrm{kWh}$ and the NWTC site is $\$ 0.051 / \mathrm{kWh}$. Using the virtual rate, the load managers would produce about a $\$ 600 /$ year savings with a simple payback of less than four years.

Table 3: Total annual energy and demand cost savings

\begin{tabular}{|l|c|c|c|}
\hline \multicolumn{1}{|c|}{ Case } & $\begin{array}{c}\text { kWh cost } \\
\text { savings }\end{array}$ & $\begin{array}{c}\text { Demand Cost } \\
\text { Savings }\end{array}$ & $\begin{array}{c}\text { Total Energy } \\
\text { Cost Savings }\end{array}$ \\
\hline \hline Load manager & $\$ 239$ & $\$ 99$ & $\$ 338$ \\
\hline Load manager \& Lights off & $\$ 407$ & $\$ 228$ & $\$ 635$ \\
\hline Lights off & $\$ 212$ & $\$ 157$ & $\$ 369$ \\
\hline
\end{tabular}




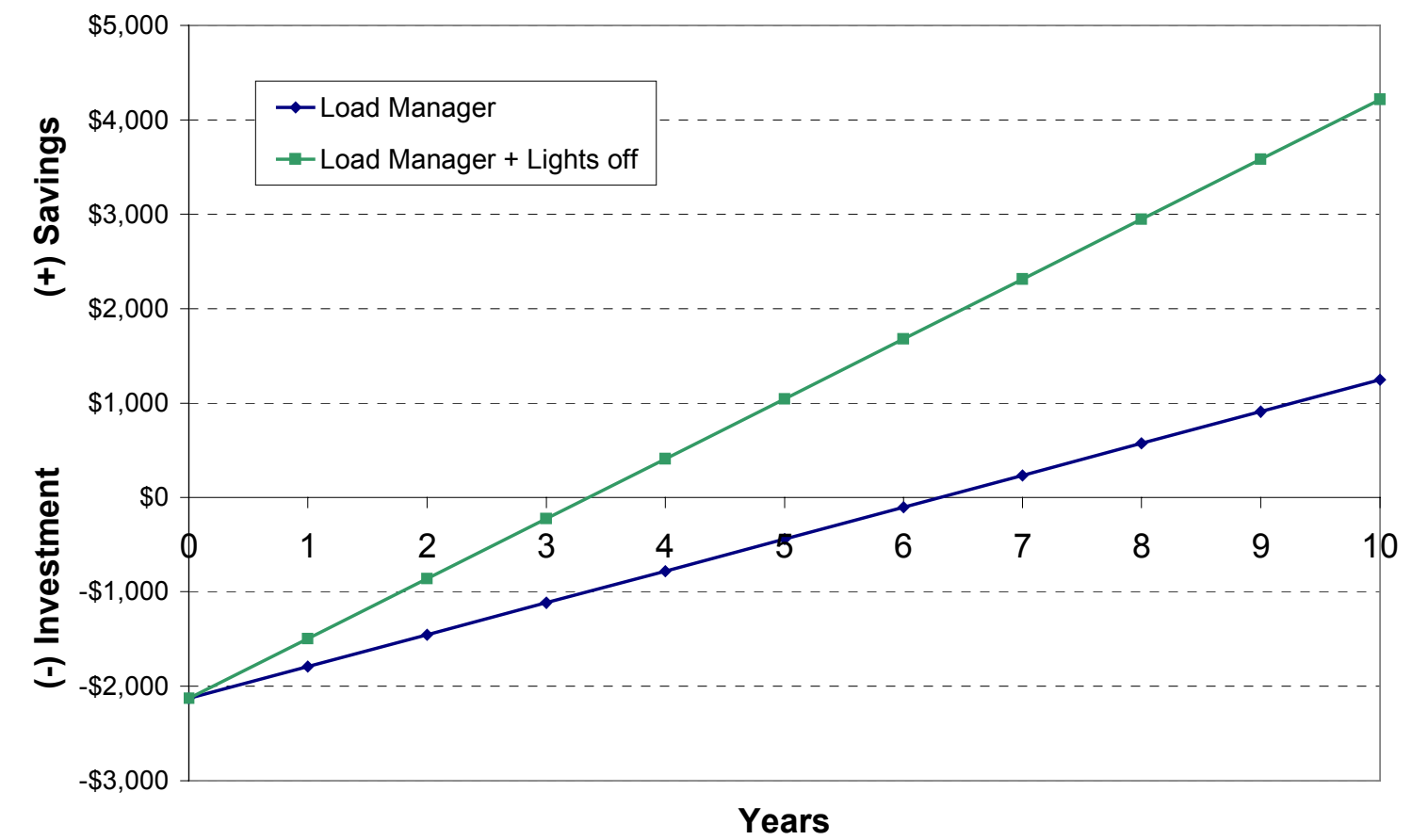

Figure 5: Projected energy cost savings for the ECMs assuming no inflation of energy costs.

\section{Conclusions}

Based on the tests performed on the various NREL cold-drink machines the following general conclusions were made:

- Typical illuminated-front cold-drink vending machines consume 7-11 kWh/day.

- Over half of the energy consumed can be saved by using the load manager and delamping the advertising lights.

- The advertising lighting uses old technology, which is very inefficient, and it should be disabled where appropriate or replaced with more efficient lighting.

The tests performed on the NREL vending machines shows that a significant amount of energy can be saved by implementing conservation techniques such as delamping and using vending machine load managers. These two methods combined can save NREL over $25 \mathrm{MWh}$ of electricity and approximately $56 \%$ in cold-drink machine operating costs. In the long run, these techniques will save money spent on electricity and aid in the sustainability of NREL.

\section{References}

[1] Chappell, C., Hanzawi, E., Bos, W., Brost, M., and Peet, R. (2002). "Does It Keep the Drinks Cold and Reduce Peak Demand? An Evaluation of a Vending Machine Control Program," 2002 ACEEE Summer Study on Energy Efficiency in Buildings Proceedings, pp. 10.47-10.56.

[2] ACEEE. (2001). The Most Energy Efficient Appliances 2001, American Council for an Energy Efficient Economy, Washington D.C. 
[3] EPA. (2003) Energy Star Labeled Vending Machines.

http://134.67.99.43/Estar/consumers.nsf/content/vending_machines.htm, Last accessed April 1, 2003.

[4] Bayview Technology Group LLC. (2003). Save Money and Energy with the Vending Miser. http://www.bayviewtech.com, last accessed April 7, 2003.

[5] Foster-Miller, Inc. (2000). Vending Machine Energy Efficiency Device Engineering Evaluation and Test Report BAY-00159. BayView Technology Group LLC, San Carlos, California.

[6] ASHRAE Standard (1997). Methods of Testing for Rating Bottled and Canned Beverage Vending Machines. 32.1-1997

[7] Canadian Standards Association. CAN/CSA-C804-96 Energy Performance of Vending Machines. September 1998. http://www.csa.ca/language/default.asp?thisUrl $=\% 2 F D e f a u l t \% 2 E a s p$ 


\section{APPENDIX A: Performance Data}

Table A.1: Vending machine locations and descriptions

\section{Tier I Data}

\begin{tabular}{|c|c|c|c|c|c|c|c|c|c|c|}
\hline No & Building & Location & $\begin{array}{c}\text { Avg. } \\
\text { Temp at } \\
\text { Location } \\
(F)\end{array}$ & $\begin{array}{c}\text { Container } \\
\text { Type }\end{array}$ & $\mathrm{Oz}$. & Capacity & Total Oz. & Manufacturer & Model \# & Serial \# \\
\hline 1 & Bldg 27 & $230-C$ & 78.4 & Bottles & 20 & 278 & 5560 & "Dixie-Narco & DN501E MC/SII-9 & 2651 6488BW \\
\hline 2 & Bldg 27 & $230-C$ & 78.4 & Cans & 12 & 475 & 5700 & Vendo & S10427013960506 & 422051 \\
\hline 3 & Bldg 17 & 2nd Floor Left & 70.1 & Cans & 12 & 471 & 5652 & Dixie-Narco & DN501E MC/SII-9 & $23836560 C X$ \\
\hline 4 & Bldg 17 & 2nd Floor Right & 70.1 & Cans & 12 & 368 & 4416 & Dixie-Narco & DNCB 368CC/216-7 & $11843116 \mathrm{BN}$ \\
\hline 5 & Bldg 16 & 2nd Floor Hall & 69.8 & Bottles & 20 & 278 & 5560 & Dixie-Narco & DN501E MC/SII-9 & $14756577 C X$ \\
\hline 6 & Bldg 16 & 2nd Floor & 69.8 & Cans & 12 & 471 & 5652 & Dixie-Narco & DN501E MC/SII-9 & $24026560 C X$ \\
\hline 7 & SERF & 1st floor & 63.9 & Cans & 12 & 471 & 5652 & Dixie-Narco & DN501E MC/SII-9 & $23396560 \mathrm{CX}$ \\
\hline 8 & SERF & 2nd floor & 69.2 & Cans & 12 & 368 & 4416 & Dixie-Narco & DNCB 368CC/216-7 & $10393116 \mathrm{BN}$ \\
\hline 9 & FTLB & Main Hall N. & 71.2 & Bottles & 20 & 278 & 5560 & Dixie-Narco & DN501E MC/SII-9 & $11396551 \mathrm{BX}$ \\
\hline 10 & FTLB & Main Hall S. & 71.2 & Cans & 12 & 471 & 5652 & Dixie-Narco & DN501E MC/SII-9 & $24066560 C X$ \\
\hline 11 & OTF & Break Room & & Cans & 12 & 471 & 5652 & Dixie-Narco & DN501E MC/SII-9 & 12516584DX \\
\hline 12 & AFUF & $1^{\text {st }}$ Floor & & Cans & 12 & 471 & 5652 & Dixie-Narco & DN501E MC/SII-9 & 12346584DX \\
\hline 13 & NWTC & Break Room & & & & & & & & \\
\hline 14 & NWTC & Break Room & & & & & & & & \\
\hline 15 & Ship \& Rec & & & & & & & & & \\
\hline 16 & SEB & Entrance & & & & & & & & \\
\hline
\end{tabular}




\section{APPENDIX A (contd.)}

Table A.2: Vending machine monitoring results for the baseline case

\section{Tier I Data}

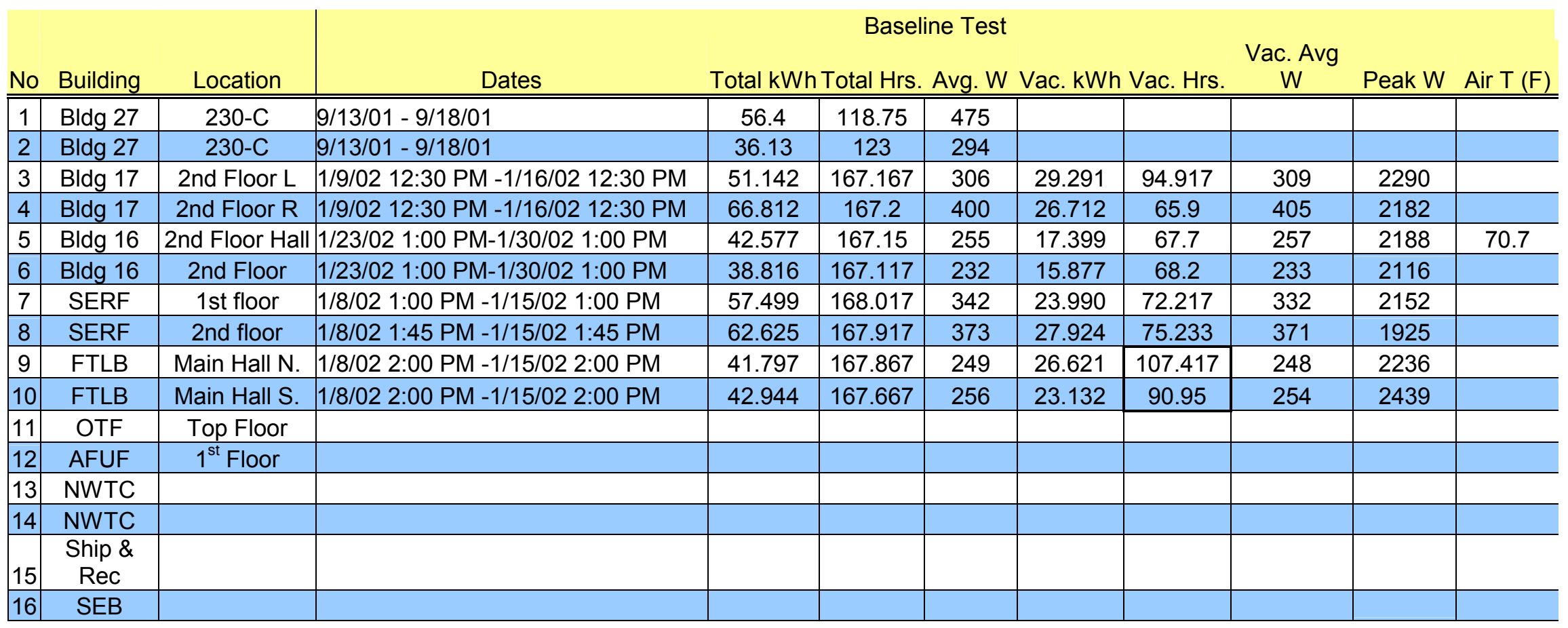

Notes:

1 - The advertising lights for machines 5, 6, 9, \& 10 were off during this test

2 - The vacant kWh \& hrs may be inflated due to motion sensor not being taped "on." It is more likely 60-70 hours. 


\section{APPENDIX A (contd.)}

Table A.3: Vending machine monitoring results for the load manager only case

\section{Tier I Data}

\begin{tabular}{|c|c|c|c|c|c|c|c|c|c|c|c|}
\hline \multirow[b]{2}{*}{ No } & \multirow[b]{2}{*}{ Building } & \multirow[b]{2}{*}{ Location } & \multicolumn{9}{|c|}{ Load Manager Only } \\
\hline & & & Dates & $\begin{array}{l}\text { Total } \\
\mathrm{kWh} \\
\end{array}$ & Total Hrs. & Avg W & Vac. kWh & Vac. Hrs. & $\begin{array}{c}\text { Vac.Avg } \\
\text { W }\end{array}$ & Peak kW & Air T (F) \\
\hline 1 & Bldg 27 & $230-C$ & $9 / 18 / 01-9 / 25 / 01$ & 54.7 & 163 & 336 & & & & & \\
\hline 2 & Bldg 27 & $230-C$ & $9 / 25 / 01-10 / 02 / 01$ & 38.18 & 167 & 229 & & & & & \\
\hline 3 & Bldg 17 & 2nd Floor L & 1/21/02 7:00 AM -1/28/02 7:00 AM & 32.461 & 168.117 & 193 & 13.824 & 104.217 & 133 & 2265 & 70.9 \\
\hline 4 & Bldg 17 & 2nd Floor $\mathrm{R}$ & 1/21/02 7:00 AM -1/28/02 7:00 AM & 41.214 & 167.983 & 245 & 5.124 & 74.3 & 69 & 2180 & 70.9 \\
\hline 5 & Bldg 16 & 2nd Floor Hall & & & & & & & & & \\
\hline 6 & Bldg 16 & \begin{tabular}{|l|} 
2nd Floor \\
\end{tabular} & & & & & & & & & \\
\hline 7 & SERF & 1st floor & 1/22/02 1:30 PM - 1/29/02 9:00 AM & 30.408 & 163.367 & 186 & 2.351 & 70.7 & 33 & 2145 & 65.4 \\
\hline 8 & SERF & 2nd floor & 1/22/02 1:30 PM - 1/29/02 9:00 AM & 30.988 & 163.25 & 190 & 3.814 & 77.967 & 49 & 1912 & 70.0 \\
\hline 9 & FTLB & Main Hall N. & & & & & & & & & \\
\hline 10 & FTLB & Main Hall S. & & & & & & & & & \\
\hline 11 & OTF & Top Floor & & & & & & & & & \\
\hline 12 & AFUF & $1^{\text {st }}$ Floor & & & & & & & & & \\
\hline 13 & NWTC & & & & & & & & & & \\
\hline 14 & NWTC & & & & & & & & & & \\
\hline 15 & Ship \& Rec & & & & & & & & & & \\
\hline 16 & SEB & & & & & & & & & & \\
\hline
\end{tabular}

Notes:

1 - The advertising lights for machines $5,6,9, \& 10$ were off during this test 


\section{APPENDIX A (contd.)}

Table A.4: Vending machine monitoring results for the load manager and delamped case

Tier I Data

\begin{tabular}{|c|c|c|c|c|c|c|c|c|c|c|c|}
\hline \multirow[b]{2}{*}{ No } & \multirow[b]{2}{*}{ Building } & \multirow[b]{2}{*}{ Location } & \multicolumn{9}{|c|}{ Load Manager \& Lights Off } \\
\hline & & & Dates & $\begin{array}{l}\text { Total } \\
\mathrm{kWh} \\
\end{array}$ & Total Hrs. & Avg W & Vac. kWh & Vac. Hrs. & $\begin{array}{c}\text { Vac.Avg } \\
\text { W }\end{array}$ & Peak kW & Air T (F) \\
\hline 1 & Bldg 27 & $230-C$ & $10 / 17 / 01-10 / 24 / 01$ & 37.786 & 164 & 230 & 17.15 & 93.533 & 183 & & \\
\hline 2 & Bldg 27 & $230-C$ & $10 / 02 / 01-10 / 09 / 01$ & 23.93 & 167 & 143 & & & & & \\
\hline 3 & Bldg 17 & 2nd Floor L & 1/30/02 1:00 PM -2/6/02 1:00 PM & 23.847 & 168.95 & 141 & 9.334 & 102.967 & 91 & 2271 & 69.3 \\
\hline 4 & Bldg 17 & 2nd Floor R & 1/30/02 1:00 PM -2/6/02 1:00 PM & 24.503 & 168.95 & 145 & 4.722 & 73.817 & 64 & 2123 & 69.3 \\
\hline 5 & Bldg 16 & 2nd Floor Hall & |1/30/02 1:00 PM -2/6/02 1:00 PM & 25.777 & 168.933 & 153 & 1.709 & 71.05 & 24 & 2121 & 69.0 \\
\hline 6 & Bldg 16 & 2nd Floor & 1/30/02 1:00 PM -2/6/02 1:00 PM & 25.359 & 168.95 & 150 & 3.530 & 70.517 & 50 & 2169 & 69.0 \\
\hline 7 & SERF & 1st floor & 1/29/02 10:00 AM - 2/5/02 10:00 AM & 20.575 & 167.7 & 123 & 1.637 & 71.467 & 23 & 2119 & 62.9 \\
\hline 8 & SERF & 2nd floor & 1/29/02 10:00 AM - 2/5/02 10:00 AM & 18.02 & 167.917 & 107 & 1.687 & 76.733 & 22 & 1839 & 62.9 \\
\hline 9 & FTLB & Main Hall N. & 1/15/02 2:00 PM -1/22/02 2:00 PM & 26.156 & 167.967 & 156 & 3.541 & 62.783 & 56 & 2247 & 71.2 \\
\hline 10 & FTLB & Main Hall S. & 1/15/02 2:00 PM -1/22/02 2:00 PM & 28.863 & 167.95 & 172 & 4.621 & 62.917 & 73 & 2431 & 71.2 \\
\hline 11 & OTF & Top Floor & & & & & & & & & \\
\hline 12 & AFUF & $1^{\text {st }}$ Floor & & & & & & & & & \\
\hline 13 & NWTC & & & & & & & & & & \\
\hline 14 & NWTC & & & & & & & & & & \\
\hline \multicolumn{12}{|c|}{15 Ship \& Rec } \\
\hline 16 & SEB & & & & & & & & & & \\
\hline
\end{tabular}




\section{APPENDIX A (contd.)}

Table A.5: Vending machine energy savings for energy conservation measures

Tier I Data

\begin{tabular}{|c|c|c|c|c|}
\hline \multirow[b]{2}{*}{ No } & \multirow[b]{2}{*}{ Building } & \multirow[b]{2}{*}{ Location } & \multicolumn{2}{|c|}{ Savings } \\
\hline & & & VM & VM \& Lights \\
\hline 1 & Bldg 27 & $230-C$ & $29 \%$ & $52 \%$ \\
\hline 2 & Bldg 27 & $230-C$ & $22 \%$ & $51 \%$ \\
\hline 3 & Bldg 17 & 2nd Floor Left & $37 \%$ & $54 \%$ \\
\hline 4 & Bldg 17 & 2nd Floor Right & $39 \%$ & $64 \%$ \\
\hline 5 & Bldg 16 & 2nd Floor Hall & $40 \%$ & * \\
\hline 6 & Bldg 16 & 2nd Floor & $35 \%$ & * \\
\hline 7 & SERF & 1st floor & $46 \%$ & $64 \%$ \\
\hline 8 & SERF & 2nd floor & $50 \%$ & $71 \%$ \\
\hline 9 & FTLB & Main Hall N. & $37 \%$ & * \\
\hline 10 & FTLB & Main Hall S. & $33 \%$ & * \\
\hline 11 & OTF & Top Floor & & \\
\hline 12 & AFUF & $1^{\text {st }}$ Floor & & \\
\hline 13 & NWTC & & & \\
\hline 14 & NWTC & & & \\
\hline 15 & Ship \& Rec & & & \\
\hline 16 & SEB & & & \\
\hline
\end{tabular}

* These machines already had the lights turned off 


\section{APPENDIX B: Testing Procedure}

The following information should be reported for Vending Machine Performance:

\section{Test 1}

- Machine type.

- Machine capacity

- Description of energy conservation measures applied to equipment (i.e. load managers, time clocks, lamp removal, etc.)

- Manufacturer, Product model number, Product serial number

- Average ambient air temperature where machine is located during each test period

- Average daily energy consumption for each test iteration

- Maximum peak power demand for each test iteration

- Characterize use patterns (standard working hours, $24 \mathrm{hr} /$ day, occasional use, etc.)

\section{Test 2}

- All of Test 1 data

- One minute current profile (Amps vs. time)

- Fifteen minute product and room air temperatures 


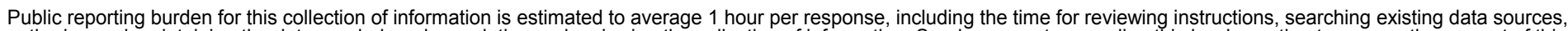

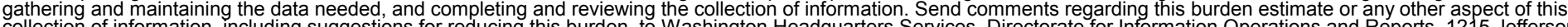

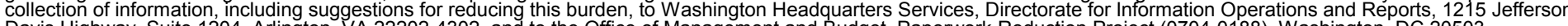

Davis Highway, Suite 1204, Arlington, VA 22202-4302, and to the Office of Management and Budget, Paperwork Reduction Project (0704-0188), Washington, DC 20503.
1. AGENCY USE ONLY (Leave blank)
2. REPORT DATE June 2003
3. REPORT TYPE AND DATES COVERED Technical report

4. TITLE AND SUBTITLE

Analysis of NREL Cold-Drink Vending Machines for Energy Savings

5. FUNDING NUMBERS

AUTHOR(S)

M. Deru, P. Torcellini, K. Bottom, and R. Ault

7. PERFORMING ORGANIZATION NAME(S) AND ADDRESS(ES)

National Renewable Energy Laboratory

1617 Cole Blvd.

REPORT NUMBER

Golden, CO 80401-3393

9. SPONSORING/MONITORING AGENCY NAME(S) AND ADDRESS(ES)

BEC3.4005

NREL/TP-550-34008

10. SPONSORING/MONITORING AGENCY REPORT NUMBER

11. SUPPLEMENTARY NOTES

12a. DISTRIBUTION/AVAILABILITY STATEMENT National Technical Information Service

12b. DISTRIBUTION CODE

U.S. Department of Commerce

5285 Port Royal Road

Springfield, VA 22161

13. ABSTRACT (Maximum 200 words) NREL Staff, as part of Sustainable NREL, an initiative to improve the overall energy and environmental performance of the lab, decided to control how its vending machines used energy. The cold-drink vending machines across the lab were analyzed for potential energy savings opportunities. This report gives the monitoring and the analysis of two energy conservation measures applied to the cold-drink vending machines at NREL.

14. SUBJECT TERMS NREL; vending machines; cold-drink vending machines; energy analysis

and monitoring.

15. NUMBER OF PAGES

16. PRICE CODE

17. SECURITY CLASSIFICATION OF REPORT Unclassified

18. SECURITY CLASSIFICATION OF THIS PAGE Unclassified
19. SECURITY CLASSIFICATION OF ABSTRACT Unclassified
20. LIMITATION OF ABSTRACT

UL 